\title{
THE ENGLISH LANGUAGE
}

IN

\section{AMERIGAN EDUGATION}

\author{
Prepared for \\ THE MODERN LANGUAGE ASSOCIATION \\ OF AMERICA
}

By

Thomas Clark Pollock, New York University

with the co-operation of

William Clyde DeVane, Yale University

and

Robert E. SpILler, Swarthmore College

COMMISSION ON TRENDS IN EDUCATION

of The Modern Language Association of America

New York, 1945

$(v i i+32$ pp.) Price 25 cents 


\section{Notice Jo All Members}

The enclosed envelope for your 1946 annual dues (\$5.00) is a device to save you postage and our understaffed office a fortnight of routine work. Dues run uniformly from January 1 st, and non-payment by October 1 st requires removal from our membership list, except for enlisted personnel in the Armed Forces. Prompt payment assists us in planning and reduces May 1st billing. Explicitly we ask that you do not incur serious inconvenience. We seek to eliminate delay through inattention.

Members of twenty years standing are advised to consider whether life membership (at fifty dollars) is not likely to prove less expensive. All money paid for life memberships is added to the Permanent Fund, largely invested in Government securities.

Faithfully yours,

PERCY W. LONG, Secretary

LYMAN R. BRADLEY, Treasurer 
American Association of Jeachers of 7 rench

\title{
ANNUAL MEETING
}

\author{
Hotel Sherman, Chicago, Illinois
}

Friday, December 28, 1945

\section{PROGRAM}

1:00 P.M. Luncheon. Short talks by M. J. J. Viala, Consul Général of France at Chicago, and M. J. W. Walch, of the French Press and Information Service at Chicago.

Address: "Paul Hazard, conscience française, conscience humaine," Professor Robert Vigneron, University of Chicago.

3:00 P.M. Business Meeting. Reports of Officers and Committees. Actions of Executive Council. New Business. Discussion. 


\title{
THE E NGLISH INST ITUTE
}

will hold its fifth session

in

\author{
New York City \\ on the invitation of
}

\section{O L U M I A U N I ERSITY}

from Monday, September 9

to Saturday, September 14

1946

The program will consist of four conference sections and several evening lectures. Full details will be given in the General Program when it is published.

\section{THE SUPERVISING COMMITTEE}

ERNest HUNTER Wright, Chairman

Columbia University

Frances A. Foster

Vassar College

DoRothy BETHuRUM

Connecticut College

Cleanth Brooks

Louisiana State University

GEORGE F. WHICHER

A mherst College

\author{
RUDOLF KIRK \\ Rutgers University \\ Elizabeth Manwaring \\ Wellesley College \\ Norman Holmes Pearson \\ Yale University \\ WiLLARd Thorp \\ Princeton University
}

Address all communications to James L. Clifford, Acting Secretary, Columbia University, New York 27,.N.Y. 


\section{JUNIOR YEAR IN ZURICH}

\section{Executive Council}

President: Alfred Senn (Pennsylvania)

Více-President: Mrs. ANNA R. Zollingm (Brooklyn)

Secretary: G. S. Dickinson (Vassar)

Treasurer: Alfred Hafner (G. E. Stechert \& Co.)

John C. BLankenagel

(Wesleyan)

Azzada Comstock (Mt. Holyoke)

Mrs. LeNa F. DAhMe (Hunter)

Herbert J. Davis (Smith)

Max Diez (Bryn Mawr)

Edgar J. Fisher (Institute of International Education)

Paul G. Graham (Smith)

Ruth HubBard (Institute of International Education)

Arthur J. May (Rochester)

W. A. NeILson (Smith, Emeritus)
Magdalene SchindzLin (Wellesley)

HENRY E. Sicerist (Hopking)

Wolfcang Stechow (Oberlin)

Lillian L. Strokbe (Vassar, Emeritus)

Wilbur K. Thomas (Carl Schurz Memorial Foundation)

Hans Vaterlaus (Siber Hegner \& Co.)

Arnold Wolfers (Yale)

A. E. ZUCKer (Maryland)

Anticipating that student passports and transportation facilities may be available by summer of 1946 , preliminary plang have been prepared for the resumption of the intercollegiate

JUNIOR YEAR IN ZURICH, IN 1946-47

Prerequisite for membership: Two years of college German and approval of the applicant's college.

Open Meeting, 11 A.M., Thursday, Dec. 27, Room 418

\section{At the Junior Year Desk, Third Floor Lobby}

Copies of the preliminary Announcement, and information may be had from a representative of the Executive Council.

After the Convention, addrese correspondence to the Director

Mr. Edmund E. Miller

1123 N. Eutaw St., Baltimore 1, Md.

"FOREIGN AREA STUDY" 


\title{
American Association of Teachers of Slavonic and East European Languages
}

\author{
Aatseel \\ President: George Bobrinskoy (University of Chicago)
}

\section{SECOND ANNUAL SESSIONS}

Room 122, Social Science Building, University of Chicago.

During M.L.A. meeting a secretary will give information daily, beginning 9:30 A.M., December 27, 1945.

\section{SECOND ANNUAL MEETING}

$5: 30$ P.M. December 29, 1945, in the above room.

Before M.L.A. sessions address: Secretary of Aatseel, 505 Philosophy Hall, Columbia University, New York 27, N.Y.

\section{AMERICAN ASSOCIATION OF TEACHERS OF GERMAN THIRTEENTH ANNUAL MEETING}

Stevens Hotel, Chicago, Illinois

Saturday and Sunday, December 29 and 30, 1945

\section{PROGRAM}

Evening Session, December 29:

7:00 Dinner. Reservations for the Dinner ( $\$ 3.50$ including gratuities) should be made in advance to Miss Elfriede M. Ackermann. Her address is Langland School, 2230 Cortland Street, Chicago; she is in charge of all arrangements.

8:30 "The German Teacher in America," Bayard Quincy Morgan, Stanford University.

Morning Session, December 30:

9:30-11:30 Papers:

"Deutsche Geschichtsschreibung und westliche Zivilisation," Arnold Bergsträsser, University of Chicago.

"Der Reim im deutschen Unterricht," Carola Geiger, De Paul University.

A third paper may be announced later.

11:30 Business Meeting. 
$\mathrm{T}$ HE fifty-seventh Annual Meeting of the American Folklore Society will be held at the Hotel Stevens, Chicago, December 27 and 28, in conjunction with the meeting of the Modern Language Association. Members of the latter Association interested in folklore are cordially invited to attend the American Folklore Society's program, which is as follows:

DECEMBER 27

Council Meeting, Room $413 \ldots \ldots \ldots \ldots \ldots \ldots \ldots \ldots \ldots \ldots \ldots \ldots$ P.M.

DeCEMBer 28

Morning Program Meeting, Room 412 ............. 9:15-11:30 A.M.

Calvin Claudel, St. Louis University, "Techniques of Recording Louisiana French Folklore Material" (10 minutes).

Alexander H. Krappe, Ecole Libre des Hautes Etudes, "A Solomon Legend among the Indians of the North Pacific Coast" (10 minutes).

Leah R. C. Yoffie, Cottey College, "Children's Singing Games in St. Louis, Missouri" (15minutes).

Francis Lee Utley, Obio State University, "Abraham Lincoln and Adam's Rib" (15 minutes).

Thelma James, Wayne University, "Wart Cures Collected in Detroit" (15 minutes).

"Current Folklore Projects and Research." Reports from: M. Bryant, American Dialect Society; L. J. Davidson, Western Folklore Conference; Charles Hofman, American Museum of Natural History, Department of Education; T. James, Modern Language Association, Popular Literature Section; Elaine Lewis, New York City Folklore Collecting; Stith Thompson, Folklore Institute of America; Newman I. White, The Brown Collection ( 5 minutes each).

Afternoon Program Meeting, Room $412 \ldots \ldots \ldots \ldots \ldots$ 2:00-4:30 P.M.

Pan. S. Codellas, University of California Medical School, "Modern Greek Folklore: The Ampodema" (15 minutes).

Ruth Underhill, U.S. Indian Office, "The Salt-Gathering Ritual of the Papago Indians" (15 minutes).

Wayland D. Hand, University of California at Los Angeles, "German Folklore in Nazi Germany" (15 minutes).

Levette J. Davidson, University of Denver, "Stories of Local Characters" (15 minutes).

Russell K. Alspach, University of Pennsylvania, "The Use by Yeats and Synge of the Celtic Folktales of Patrick Kennedy" (20 minutes).

Harriet Pawlowska, Persbing High Scbool, Detroit, "Tendencies of the Polish Folksong and Folksinger in America" (15 minutes).

Business Meeting, American Folklore Society, Room $412 \ldots \ldots \ldots 4: 30$ P.M.

Evening Meeting, Room $412 \ldots \ldots \ldots \ldots \ldots \ldots \ldots \ldots \ldots \ldots \ldots \ldots \ldots$ P.M.

Archer Taylor, University of California

"Problems of Folklore"

Melville J. Herskovits, Northwestern University

President, American Folklore Society, 1945

"Folklore After a Hundred Years-A Re-definition" 
Just too late to make this conference no but ready soon on $A$ New Edition of

\section{LIPPMANN \& NEVINS'S \\ A MODERN READER}

This leading college "reader" gives as illuminating an introduction to modern life and thought as the first edition gave to the years immediately preceding World War II. Many new essays on current, vital issues by leading thinkers in a wide variety of fields have replaced some older selections. These newer essays, together with those retained because of their continued social, cultural, and literary importance, provide a stimulating background for student opinion and serve as examples to guide college freshmen in their own thinking and expression.

\section{Among those present on friends old and new}

WOOLLEY \& SCOTT: College Handbook of Composition, Fourth ed. 464p. \$1.50

BRYANT: A Functional English Grammar. 336p. \$2.00

Espenshade, Gates \& Mallery: The Essentials of English Composition, Rev. 467p. $\$ 2.00$

Simpson, BRown \& STEGNER: The Research Paper. $60 p . \$ 50$

Simpson \& Nevins: The American Reader. $884 p . \$ 2.50$

MORRISON \& OTHERs: Five Kinds of Writing - selections from British and American authors, old and new. $679 p . \$ 2.50$

Brooke \& Paradise: English Drama, 1580-1642. $1052 p . \$ 4.00$

SpENCER: Elizabethan Plays. 1181p. $\$ 4.00$

D. C. HEATH AND COMPANY 


\section{Victory Exbibit on}

\section{of Heath's Modern Language Texts}

ono Come to Heath's book exhibit booth if you want to see in concrete form the powerful effects the war has had on modern language teaching. Twenty-four separate publications there displayed are witness to your recent war experience of having to train students, within a few brief months' time, to speak a foreign language.

one Today, after victory, not only modern language teachers, but a large part of the general American public as well, are convinced of the vital necessity for maintaining primary emphasis on spoken languages. Their conviction has grown from the widespread realization that a speaking knowledge of foreign languages is the most important key to international understanding and furtherance of the peace.

on It is also our belief that the spoken language has come to stay as the indispensable means of communication among interdependent nations in a small world. To our twenty-four publications in spoken languages we will soon be adding a dozen more, now in preparation or in press. We are confident that among all our texts (in conversation, reading, or writing) instructors will also find those that meet their needs and appeal to their tastes for the more leisurely and culturally rich courses of the present and future.

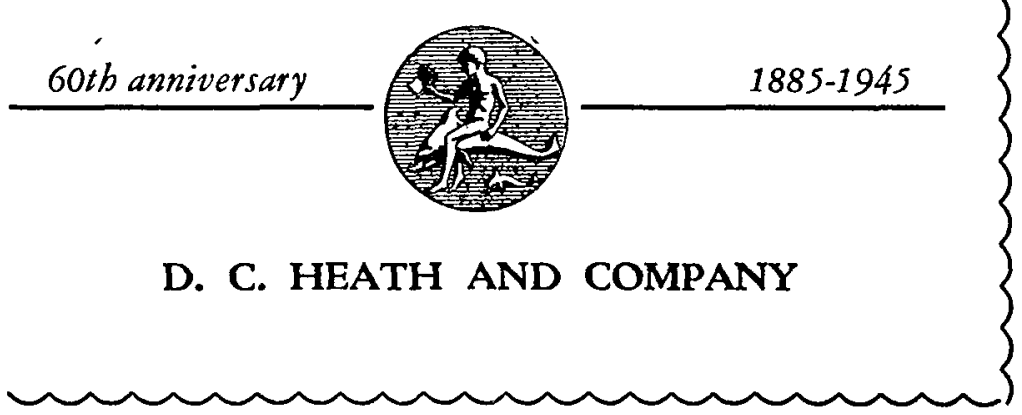




\section{The \\ STYLISTIC DEVELOPMENT of $\mathbb{K E A T S}$}

BY

WALTER JACKSON BATE

Member of the Society of Fellows, Harvard University

$\leadsto$

NEW YORK

THE MODERN LANGUAGE ASSOCIATION OF AMERICA

LONDON : OXFORD UNIVERSITY PRESS

MCMXLV

Revolving Fund Series XIII. Price $\$ 3.00$ 


\section{GERMAN BOOKS} Publisher and Bookseller

NEW BOOKS: We are exclusive representatives of the most important publishers of German books in America, Switzerland, Sweden and England. Ask for our new catalogue number 31 . On new books we grant teachers and libraries a discount.

PERIODICALS: We are exclusive distributors of DIE NEUE RUNDSCHAU and DEUTSCHE BLXTTER.

SECONDHAND BOOKS: We have the largest stock in America. We buy secondhand books continuously and pay you the highest possible prices. Ask for our many special lists of books comprising all flelds of literature.

OUR OWN PUBLICATIONS: DIE SCHONSTEN DEUTSCHEN LIEDER IUM Singen und zum Spielen. Erste Folge 21 songs, 48 pages, paper $\$ 1.00$ Zweite Folge 18 songs, 48 pages,

paper $\$ 1.00$

JUHN, Kurt: Der Hexenhammer. With 8 original lithographs by Erich Godal. Numbered edition 32 pages, cloth $\$ 2.25$

KAHN, Fritz: First Aid. With more than 100 instructive illustrations. Remainder of the 1st edition

2nd revised edition paper \$0.25 cloth $\$ 0.75$

MEYER, Oscar: Von Bismarck zu Hitler. Erinnerungen und Betrachtungen. 240 pages, with the author's portralt and list of names, cloth $\$ 2.75$

OSBORN, Max: Der bunte Splegel. Erinnerungen aus dem Kunst-, Kultur- und Geistesleben 1890 bis 1933 . With 5 facsimiles and 2 pictures. 290 pages, cloth $\$ 3.75$ Numbered and signed copy, cloth $\$ 5.00$

PERL, Walter H.: Thomas Mann 1933 bis 1945. Vom deutschen Humanisten zum amerikanischen Weltblirger.

64 pages, board $\$ 1.50$ (Suitable for classroom-readingl)

ROSENTHAL von GROTTHUSS, Alfred: Kein Dritter Weltkrieg! With the author's portrait and list of names. 211 pages, cloth $\$ 2.75$

URZIDIL, Johannes: Der Trauermantel. Eine Erzählung aus Adalbert Stifters Jugend und Kindheit. 72 pages,

cloth $\$ 1.50$

(Especially recommended for classroom-reading!) Numbered and signed copy, cloth $\$ 2.50$

DOKUMENTE DES ANDEREN DEUTSCHLAND:

Volume I: Goerdelers Politisches Testament. With one lithograph by Stumpt, one facsimile and a list of names. 72 pages, cloth $\$ 1.60$

Volume II: Ernst Jfinger. Die Wandlungen eines deutschen Dichters und Patrioten. By Karl O. Paetel. With one portrait. 72 pages, cloth $\$ 1.75$

Volume III: Deutsche Innere Emigration. Complled and interpreted by $\mathrm{Karl} O$. Paetel, Dorothy Thompson, Carl Zuckmayer and others. Articles by Bergengrün, Bischof von Galen, Goerdeler, Jünger, Walter von Molo, Pastor Niemoller, Frank Thiess, Ernst Wiechert and many others. (In preparation.)

Volume IV: Deutsche Märtyter in Konzentrationslagern. By Heinz Langerhans. (In preparation.)

Volume V: Lyrik aus dem Deutschland von 1944.

(In preparation.)

$H$ See our book-exhibition at the convention in Chicagol We specialize in German books only. 


\section{Viaje de Negocios}

Jaime Homero Arjona, University of Connecticut

232 pages $\$ 1.80$

\section{Vasco Núñez de Balboa}

Octavio Méndez Pereira, Formerly President, University of Panama Everett W. Hesse, University of Wisconsin

268 pages $\$ 1.60$

\section{A New Approach to Spanish First Year Second Year 636 p. $\$ 1.96$ 688 p. $\$ 2.12$ \\ Louis Cabat, Midwood High School, Brooklyn, N.Y. George Fanning, Jr., Curtis High School, Staten Island, N.Y.}

\section{Practical Spanish Grammar}

H. B. Holmes, Univessity of Kentucky

J. E. Hemández, United States Military Academy 242 pages $\$ 1.30$

\section{Spanish Review Grammar}

Everett $\mathrm{W}$. Hesse, University of $W$ isconsin 156 pages $\$ 1.40$

\section{Buenos Amigos, Buenos Vecinos}

Raymond L. Grismer, University of Minnesola César I. Arroyo, Latin-American Studio, St. Paul 126 pages $\$ 1.20$

\section{El Gaucho y La Pampa}

L. Clark Keating, George Washington Universioy Joseph S. Flores, University of Illinois 193 pages $\$ 1.40$

\section{American Book Company}




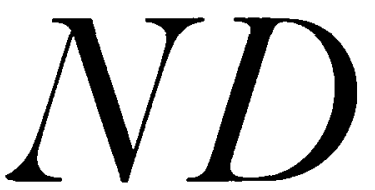

\section{SELECTIONS OF CLASSIC POETRY}

Pamphlet 50\&; Boards $\$ 1$

Some Poems and a Devotion of Donne

Some Poems by Herrick

Selected Poems of Melville

More Poems from the Palatine Anthology, trans. by Fitts

Some Odes of Pindar, trans. by Lattimore

A Satire Against Mankind and Other Poems by Rochester

3 Russian Poets, Selections from Pushkin, Lermontov, and Tyutchev, trans. by Nabokov

The Book of Hours by Rilke, trans. by Deutsch (German incl.)

\section{MAKERS OF MODERN LITERATURE}

\section{$\$ 1.50 \mathrm{EACH}$}

James Joyce by Levin

Virginia Woolf by Daiches

E. M. Forster by Trilling

Gogol by Nabokov

Lorca by Honig

G. M. Hopkins by The Kenyon Critics

T. S. Eliot by Schwartz

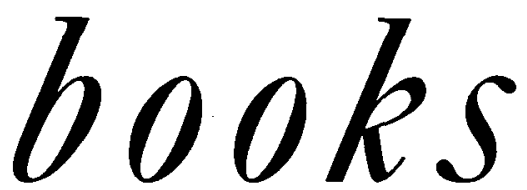

are well-printed, inexpensive texts suitable for class-room study and assigned reading.

\section{THE NEW CLASSICS}

\section{$\$ I$ EACH}

A Season in Hell by Rimbaud (with French)

Three Lives by Stein

A Room With a View

by Forster

Amerika by Kafka

The Longest Journey

by Forster

The Spoils of Poynton

by Henry James

Three Tales by Flaubert

A Handful of Dust

by Evelyn Waugh

\section{OTHER N D BOOKS}

Stephen Hero

by James Joyce. $\$ 3.5^{\circ}$

Faust

by Goethe. (German \& English). $\$ 3.00$

Stories of Artists \& Writers

by Henry James. $\$ 3.5^{\circ}$ 


\section{THE MACMILLAN COMPANY \\ and the}

\section{CAMBRIDGE UNIVERSITY PRESS}

cordially invite you to visit their book exhibit at the 1945 Convention of The Modern Language Association of America where you will have an opportunity to look over the new and important works in your special field of interest and where our representatives will give you information about our forthcoming books.

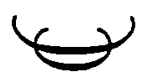




\section{OXFORD BOOKS by MEMBERS of the MODERN LANGUAGE ASSOCIATION}

These and other books of interest to members of the Association will be on display at the Oxford University Press booth. We cordially invite you to stop by and examine them.

ADAMS, NICHOLSON B., \& GRISMER, RAYMOND L. Tales from Spanish America. $\$ 1.75$

AYDELOTTE, FRANK. Elizabethan Rogues -and Vagabonds. \$3.50

BARTON, FRANCES BROWN, \& MCMASTER, A. C. Sardou's Les Femmes Fortes, 90 BAUDIN, MAURICE. Dumas's Antony. $70 \phi$

and BRANDON, EDGAR EWING. Dumas's Henri III et sa cour. \$1.05

Lesage's Turcaret. $85 \notin$

BEACH, LEONARD B., \& WILLIAMS, STANLEY THOMAS. The Journal of Emily Foster. $\$ 5.00$

BELL, CLAIR HAYDEN. Grillparzer's Weh dem, der Lügt! \$1.05

BENTLEY, GERALD EADES. The Jacobean and Caroline Stage. $\$ 12.50$

BERDAN, JOHN MILTON. Fourteen Stories from One Plot. \$1.25

BLANCHARD, RAE. The Correspondence of Richard Steele. $\$ 10.00$

BRANDON, EDGAR EWING, \& BAUDIN, MAURICE. Dumas's Henri III et sa cour.

$\$ 1.05$

Lesage's Turcaret. $85 \$$

BROOKE, C. F. TUCKER. Marlowe's Work. $\$ 2.00$

Shakespeare's Sonnets. $\$ 5.00$

Shakespeare: Apocrypha. $\$ 3.00$

BUCK, PHILO MELVIN, JR. Directions in Contemporary Literature. College edition, \$2.25

BUSSE, ADOLPH. Selections from Goethe's Prose. \$1.05

CAMPBELL, O. J. Shakespeare's Satire. $\$ 3.75$

CHASE, STANLEY P. The Pearl (in modern verse). $\$ 1.00$

CHEW, SAMUEL CLAGGETT. The Crescent and the Rose. $\$ 5.00$

CILLEY, MELISSA, \& SCANLON, C. L. First Portuguese Reader. $\$ 1.50$

CLIFFORD, JAMES LOWRY. Hester Lynch Piozzi. \$6.50

COOPER, LANE. Plato. College edition, $\$ 2.50$

Fifteen Greek Plays. $\$ 3.00$

CRAIG, HARDIN. The Enchanted Glass. $\$ 2.50$

CURRY, WALTER CLYDE. Chaucer and the Medieval Sciences. $\$ 2.50$

DAVIS, HERBERT JOHN. Swift's The Drapier's Letters. $\$ 7.00$

DEY, WILLIAM MORTON. Constant's Adolphe. $90 ф$

DIECKHOFF, JOHN SIEMON. Milton on Himself. $\$ 3.50$

DIEZ, MAX. Introduction to German. \$1.85

DODDS, JOHN WENDELL. Thackeray: A Critical Portrait. $\$ 3.00$

and WHITRIDGE, ARNOLD. An Oxford Anthology of English Prose. \$3.25

DUNN, WALDO H., \& STEPHENSON, N. W. George Washington. $\$ 10.00$

EATON, HORACE AINSWORTH. Thomas De Quincey. $\$ 5.00$

ECKELMANN, ERNEST OTTO. Droste-Hülshoff's Die Judenbuche. $\$ 1.00$

ENTWHISTLE, WILLIAM JAMES. European Balladry. $\$ 5.50$

Cervantes. $\$ 2.50$

ESPINOSA, AURELIO MACEDONIO. España. $30 ф$

Historia de la Literatura Española. \$1.85

ESPINOSA, AURELIO MACEDONIO, JR. Cuentitos Faciles. 304

Cuentos Castellanos. $30 \phi$

EWING, MAJL, \& McINTYRE, C. F. English Prose of the Romantic Period. \$2.35

FEISE, ERNST. Goethe's Die Leiden des jungen Werthers. $\$ 1.20$

FERGUSON, JOHN DE LANCEY. Letters of Robert Burns. $\$ 9.50$

FOERSTER, NORMAN. American Critical Essays (XIX-XX Centuries). 95\$

GEDDES, JAMES, JR. French Pronunciation. \$1.50

GEROUID, GORDON HALL. Ballad of Tradition. \$4.25

GRAHAM, WALTER JAMES. The Letters of Joseph Addison. $\$ 8.00$

GREENE, RICHARD LEIGHTON. The Early English Carols. $\$ 10.00$ 
GRIGGS, EARL LESLIE. Coleridge Fille. \$3.75

New Poems of Hartley Coleridge. $\$ 3.00$

and GRIGGS, G. E. Letters of Hartley Coleridge. \$1.75

GRISMER, RAYMOND L., \& ADAMS, NICHOLSON B. Tales from Spanish America $\$ 1.75$

GUDDE, ERWIN G. Vesper's Gute Geister. $90 \%$

GUYER, FOSTER ERWIN. Sand's L'Homme de neige. $95 \$$

and BOVEE, A. G. Vingt contes favoris. $\$ 1.65$

HAMILTON, D. LEE, \& FAHS, NED C. Anedotas Fáceis. $30 \$$

HARPER, GEORGE MCLEAN. WORDSWORTH'S POEMS (Introduction and Notes). $\$ 1.50$

HARRIS, JESSE W., ROBERTS, C. W., \& JOHNSON, W. G. A Handbook of English. $\$ 1.35$

HARROLD, CHARLES FREDERICK, \& TEMPLEMAN, WILLIAM DARBY. English Prose of the Victorian Era. \$4.75

HART, JAMES DAVID. The Oxford Companion to American Literature. $\$ 5.00$

HARTMAN, HERBERT WEIDLER, JR. A Petite Pallace of Pettie His Pleasure. $\$ 6.50$ HAUCH, EDWARD F. Essential German. \$1.75

HEWITT, THEODORE BROWN. Idiomatic German Composition. \$1.10

HOFACKER, ERICH. Great German Dramas Retold. \$1.15

HOLZKNECHT, KARL J. A Literary Map of the British Isles. $10 \phi$

JOHNSON, WALTER G., ROBERTS, C. W., \& HARRIS, J. W. A Handbook of English. \$1.35

JOHNSTON, MARJORIE C. Molina's Los Tres Maridos Burlados. $30 \notin$

JONES, W. POWELL. Practical Word Study. $\$ 1.00$

KENNEDY, CHARLES W. Beowulf. \$1.75

The Earliest English Poetry. \$3.00

KURZ, HARRY. Prevost's Manon Lescaut. $\$ 1.20$

LANCASTER, H. CARRINGTON. Principal Rules of French Pronunciation. $15 \notin$ and otbers. On Going to College. \$1.85

LANGLEY, ERNEST F. Beaumarchais's Le Mariage de Figaro. \$1.15

LEARNED, HENRY DEXTER. Modern Introductory French Book. 1.75

LEMAITRE, GEORGES E. Four French Novelists. $\$ 3.50$

LIEDER, FREDERICK WILLIAM CHARLES. German Poems and Songs. \$1.75 Goethe's Hermann und Dorothea. \$1.15

Schiller's Don Carlos. \$1.55

IOPEZ, ALBERT R. Bengoa's El Recién Nacido. $30 \notin$

LOWRY, HOWARD FOSTER. Letters of Matthew Arnold to Arthur Hugh Clough. $\$ 3.50$ and TINKER, CHAUNCEY B. The Poetry of Matthew Arnold: A Commentary. $\$ 3.50$ and THORP, WILLARD. An Oxford Anthology of English Poetry. \$3.25

MACMILLAN, DOUGALD. Drury Lane Calendar. $\$ 7.00$

MANWARING, ELIZABETH WHEELER, \& WARFEL, HARRY R. Of The People. $\$ 2.30$

MARCKWARDT, ALBERT $H$. Introduction to the English Language. \$2.15

MARTIN, JOHN L. Palacio's El Alférez Real. \$1.35

MCADAM, EDWARD L., JR., \& SMITH, D. NICHOL. The Poems of Samuel Johnson. $\$ 7.50$

MORE, ROBERT PATTISON, \& PALMER, PHILLIP MASON. Sources of the Faust Tradition. $\$ 3.50$

MORGAN, BAYARD QUINCY. Leskien's Schuld? 85d

MULLER, HENRY FRANCOIS, \& VAILLANT, RENE E. G. Rousseau's Discours. $80 \notin$ MUNN, JAMES BUELL, and others. On Going to College. \$1.85

NORDMEYER, HENRY W., \& RICHTER, K. E. Introduction to Commercial German. $95 \%$

OLMSTED, RICHARD H. El Abencerraje. $30 \%$ Isaacs' Maria. $30 \notin$

OSBORN, ANNIE MARION. Rousseau and Burke. $\$ 3.75$

OSGOOD, CHARLES GROSVENOR. Milton's Poetical Works (Introduction). \$1.50

PALMER, PHILLIP MASON, \& MORE, ROBERT PATTISON. Soutces of the Faust Tradition. $\$ 3.50$

PARROTT, THOMAS MARC, \& THORP, WILLARD. Poetry of the Transition, 1850 1914. College edition, $\$ 3.00$

PATCH, HOWARD ROLLIN. The Tradition of Boethius. $\$ 2.75$

PATTISON, WALTER T. Representative Spanish Authors. $\$ 4.00$. In two vols., $\$ 2.25$ ea. 
PEARSON, NORMAN HOLMES, \& BENET, WILLIAM ROSE. The Oxford Anthology of American Literature. One volume \$4.50. Vol. I (to Walt Whitman) \$2.50; Vol. II $\$ 3.00$

PLACE, EDWIN B., \& TORRES-RIOSECO, A. Contemporary Spanish Grammar. $\$ 1.80$ POTTLE, FREDERICK ALBERT, and others. Index to Private Papers of James Boswell. $\$ 21.00$

PRICE, LAWRENCE M. Wildenbruch's Lachendes Land. 95

PUCKETT, HUGH WILEY. Keller's Sieben Legenden. $\$ 1.25$

PURDY, RICHARD LITTLE. Sheridan's The Rivals. $\$ 7.50$

RUSSELL, HARRY J. The Most Common Spanish Words and Idioms. Revised and enlarged edition ready shortly. 304

SAMPSON, HARRIET. Evelyn's The Life of Mrs. Godolphin. \$3.50

SARGENT, RALPH MILLARD, At the Court of Queen Elizabeth. $\$ 3.50$

SCHENCK, EUNICE MORGAN, \& CHERON, J. Handbook of French Correspondence. $85 \dot{8}$

SCHONS, DOROTHY. Molina's Los Tres Maridos Burlados. 304

SCHREIBER, CARL FREDERICK, \& PIERCE, F. E. Fiction and Fantasy of German

Romance. $\$ 1.85$

SCUDDER, TOWNSEND. The Lonely Wayfaring Man. \$1.75

SHACKFORD, MARTHA HALE. Letters from Elizabeth Barrett to B. R. Haydon. $\$ 2.00$

SHERBURN, GEORGE. The Early Career of Alexander Pope. $\$ 5.00$

SIMMONS, ERNEST JOSEPH. Dostoevski: The Making of a Novelist. $\$ 3.00$

SMITH, DANE FARNSWORTH. Plays About the Theatre in England. \$4.00

STEINHAUER, HARRY. Deutsche Kultur. $\$ 1.90$

and JESSIMAN, H. Modern German Short Stories. $95 \notin$

TEMPLEMAN, WILLIAM DARBY, \& HARROLD, CHARLES FREDERICK. English Prose of the Victorian Era. \$4.75

THOMPSON, HAROLD WILLIAM. Scottish Man of Feeling: Some Account of Henry Mackenzie. $\$ 5.00$

THORP, WILLARD, \& LOWRY, HOWARD FOSTER. An Oxford Anthology of English Poetry. \$3.25

and PARROTT, THOMAS MARC. Poetry of the Transition, 1850-1914. College edition, $\$ 3.00$

THORPE, CLARENCE DE WITT. The Mind of John Keats. \$2.50

TINKER, CHAUNCEY B. Boswell's Letters. Two vols., $\$ 12.00$

and LOWRY, HOWARD FOSTER. The Poetry of Matthew Arnold: A Commentary. $\$ 3.50$ and otbers. On Going to College. $\$ 1.85$

TORRES-RIOSECO, ARTURO, and LóPEZ, A. R. Bengoa's El Recién Nacido. $30 \Varangle$ and PLACE, EDWIN B. Contemporary Spanish Grammar. $\$ 1.80$

TUPPER, FREDERICK, and

TUPPER, JAMES WADDELL. Representative English Dramas from Dryden to Sheridan. $\$ 3.00$

UPHAM, ALFRED HORATIO. Typical Forms of English Literature. \$1.25

VAIL, CURTIS C. D. Graded German Short Stories. $\$ 1.25$

VAN SANTVOORD, GEORGE. Fowler's Pocket's Oxford Dictionary (American educational edition). \$1.15

WARFEL, HARRY R., \& MANWARING, ELIZABETH WHEELER. Of the People. \$2.30 WARREN, VIRGIL ALEXANDER, \& SWAIN, JAMES O. Galarraga's El Heroe. \$1.25 WEBER, CARL. J. Hardy's Far from the Madding Crowd. $\$ 1.00$

WEEKS, RAYMOND. Musset's Quatre comédies, \$1.10

WHITRIDGE, ARNOLD, \& DODDS, JOHN WENDELL. An Oxford Anthology of English Prose. $\$ 3.25$

WICHELNS, HERBERT AUGUST, and otbers. On Going to College. \$1.85

WILLIAMS, CHARLES ALLYN. Raabe's Die schwarze Galeere. $\$ 1.25$

WILIIAMS, STANLEY THOMAS. The Life of Washington Irving. $\$ 10.00$ The Journal of Washington Irving, 1803. $\$ 3.00$

and BEACH, LEONARD B. The Journal of Emily Foster. $\$ 5.00$

and EDGE, M.E. A Bibliography of the Writings of Washington Irving. $\$ 5.00$

YOUNG, BERT EDWARD. Molière's Le Tartuffe. $90 \%$

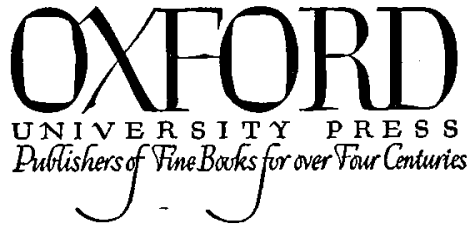




\section{The Index Society}

I NVITES YOU TO MEMBERSH P

Despite wartime difficulties, the two volumes described below have been distributed to members, and copies will be available to those who join while the books are still in print. They may be seen at this meeting in the display of Columbia University Press.

The Index of Middle English Verse. By Carleton Brown and Rossell Hope Robbins. pp. xix-785.

Every known poem written in English between 1200 and 1500 is included in the Index, with subject, rhyme form, location of manuscripts, and lists of printed appearances. With 4365 entries as against the 2273 in Brown's Register, this volume renders the earlier work obsolete.

Short-title Catalogue of Books Printed in England, Scotland, Ireland, Wales, and British America, and of English Books Printed in Other Countries: 1641-1700. Compiled by Donald Wing of the Yale University Library. Volume I (A-England, inclusive).

The remaining two volumes of the Short-Title Catalogue will be published as soon as possible, Volume II now being in galley proof. Other important tool-books for literary and historical scholarship will follow.

Dues (ten dollars per year) entitle members to the annual publications, which are not available to non-members except at sharply advanced prices.

Inquiries and applications for membership should be directed to the Secretary of the Index Society, Harold W. Bentley, 2960 Broadway, New York 27, New York.

\section{Editorial Committee of The INDEX SocIETY}

Benjamin C. Nangle, Chairman

Yale University

George Sherburn, Harvard

Wallace Notestein, Yale
Harold W. Bentley, SecretaryTreasurer, Columbia Univ.

James M. Osborn, Yale

Lawrence C. Wroth, Brown 